\title{
The More Things Change, the More They Stay the Same: The Elusive Search for Racial Equity in Higher Education
}

\author{
K. Edward Renner* \\ Evaluation Research
}

\section{Thom Moore}

University of Illinois

In 1965, when affirmative action officially became part of the national consensus to achieve racial social justice, it was based on the compelling justification of establishing equality and remedying the effects of past discrimination. Since then, there has been a slow but steady shift from "equity" to "diversity" as its rationale. The shift has had a negative effect on achieving the original goal of racial equality. The diversity rationale has permitted parallel procedures to evolve that provided majority students with an even larger differential advantage than that conferred on minority students by affirmative action. In addition, we continue to have massive segregation. Minorities are concentrated in second level schools in urban areas, while whites are concentrated in higher quality institutions in the educational suburbs. It is without factual or legal foundation that whites can argue that they (relative to minorities) are the victims of discrimination through unfair and unequal educational policies and practices that determine access to higher education.

Under President Johnson (1965a) affirmative action officially became part of the national consensus to achieve racial social justice. Executive Order 11246 was based on the compelling justification of establishing equality and remedying the effects of past discrimination (Allen, Teranishi, Dinwiddie \& Gonzales, 2000; Johnson, 1965b). However, since 1978 when the Supreme Court acknowledged the educational value of a racially diverse campus (Regents of the University of California v. Bakke) there has been a slow but steady shift from "equity" to

\footnotetext{
* Correspondence concerning this article should be addressed to Edward Renner, Evaluation Research, 14241 110th Terrace, Largo, FL 33774 [e-mail: erenner@kerenner.com].
} 
"diversity" as the rationale for affirmative action within higher education (Allen, 2000). This shift has had a negative effect on actually achieving the original goal of affirmative action of racial equality. It is our conclusion that it is without factual or legal foundation that whites can argue that they (relative to minorities) are the victims of discrimination through unfair and unequal educational policies and practices that determine access to higher education.

If our conclusion is to be supported, it will be necessary to show that: (1) whites have made greater gains in access to higher education than minorities over the period of affirmative action; (2) there is currently massive segregation in higher education; (3) the relative white advantage is the result of parallel procedures that have provided majority students with an even larger differential advantage than any advantage conferred by affirmative action on minority students; (4) if equity, rather than the diversity, had remained the focus - as it was in Brown v. The Board of Education in 1954-the courts now would be in a position to enforce, rather than limit, the role of affirmative action in access to higher education; (5) the most direct and effective way to actually achieve the social and educational benefits of a racially diverse campus and society is to acknowledge that the diversity rationale has been a deception of the evolutionary progress when the net effect has been to maintain the status quo; (6) there are simple, direct, and feasible mechanisms for returning to the equity rationale; and (7), there are compelling social, economic, educational, and demographic reasons for doing so.

\section{Illusions of Change}

Minorities are clearly better off today than they were in 1954, both in terms of the numbers and percentages graduating from college. But, so too is everyone else in America. In fact, over the period of affirmative action, whites have made greater gains than either blacks or Hispanics (see Figure 1).

The American Council on Education (2003) obtained identical findings using the alternative statistic of participation rates. In their annual report on race, which began in 1980, they emphasize that the gap between the participation rates of whites and those of blacks and Hispanics has increased substantially over the past 20 years.

The appropriate statistical standards are neither the absolute number of minority students, nor the percentage increase over the previous year, who graduate or participate. The appropriate statistics are measures of relative access because of the huge increase in general access. Figure 2 re-plots the data from Figure 1 to show both the annual absolute percentage gains by blacks, which has increased steady over the past 60 years for which comparable data are available, and the relative size of those gains as a percentage of the annual gains made by whites. The 60-year average in relative gains by blacks from 1940 to the present is zero. 
Elusive Search for Racial Equity in Higher Education

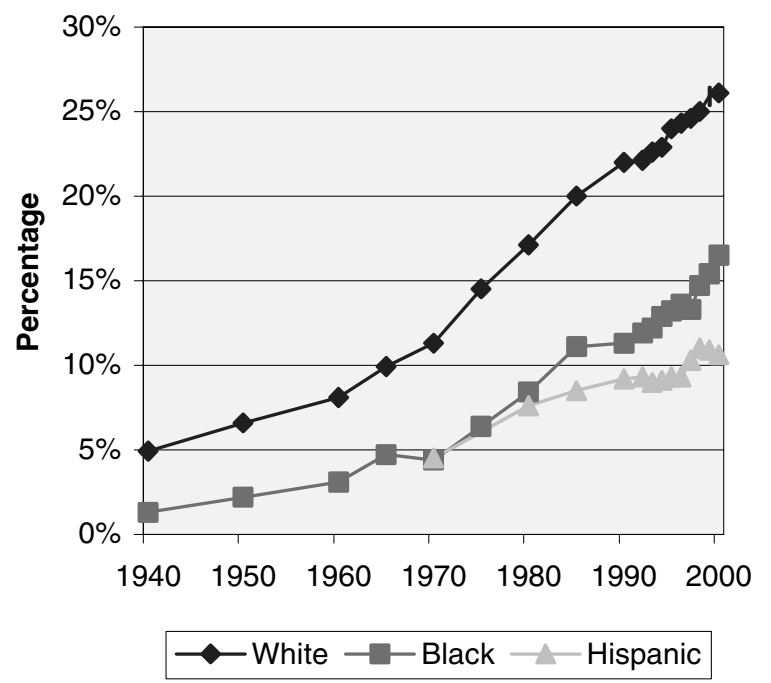

Fig. 1. College graduation rate by race. The percentage of individuals over 25 years of age who have completed four or more years of college. Data from U.S. Bureau of Census. See Statistical Abstracts of the US, 2002a for recent data.

\section{Relative Versus Absolute Black Gains}
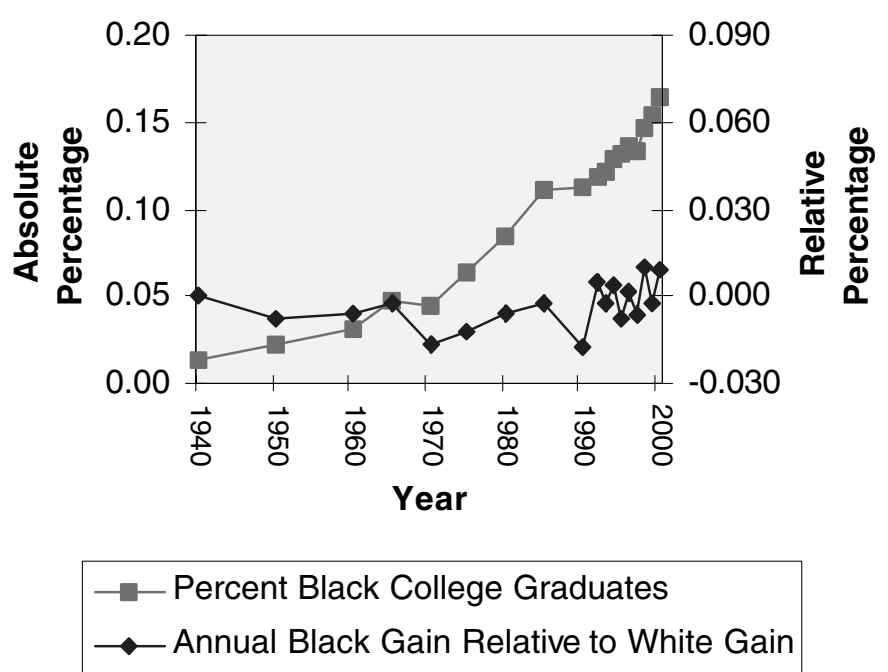

Fig. 2. Relative versus absolute gains by blacks. This figure re-plots the data from Figure 1 showing the number of blacks over 25 who have four or more years of college in comparison to the gains made by whites over the same time period. 


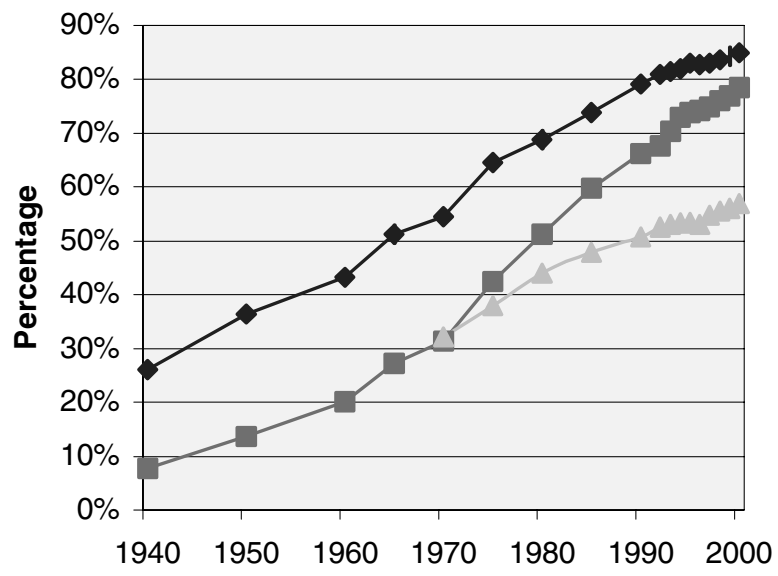

$\neg$ White $\neg-$ Black $\rightarrow$ Hispanic

Fig. 3. High school graduation rate by race. Percent of individuals over 25 years of age who have completed high school. Data from U.S. Department of Census. See Statistical Abstracts of the US, 2002a for recent data.

The failure of blacks and Hispanics to make gains in terms of either graduation rates from college or participation rates cannot be due to the lack of graduation from high school. That gap has closed over the same time period for blacks and remained relatively constant for Hispanics (see Figure 3 ). The steady improvement in high school graduation rates should have resulted in relatively greater gains in college graduation rates by blacks rather than by whites.

Clearly, minority students are in the supply line but have not participated in the huge expansion of access to higher education at the same rate as whites over the period of affirmative action. Thus, despite the presumed advantage given to minorities over majority applicants through affirmative action, the net effect has been for greater relative gains by majority students.

\section{De Facto Segregation in Higher Education}

There is strong and persistent evidence of significant racial segregation along geographic and institutional quality characteristics. Minorities are concentrated in second level schools in urban areas. Whites are concentrated in higher quality institutions in the educational suburbs.

Data on the racial breakdown of enrollment in higher education are collected annually by the National Center for Educational Statistics (NCES). The data for the 2000-1 academic year were released in 2003, the most recent 
available. The analysis that follows is based on the 3,684 institutions that offer two-year or more academic programs that are classified by the Carnegie Foundation and have accreditation recognized by the U.S. Department of Education. These institutions accounted for 14.2 million U.S. students of known race; excluded from the analysis were an additional .5 million foreign students and .8 million students of unknown race. The raw data file can be downloaded from NCES (2003a).

The 96 Historical Black Colleges and Universities account for only 3\% of all institutions but enroll $13 \%$ of all black students, or one of every seven. In a similar way, the 52 colleges and universities of Puerto Rico enroll $11 \%$ of all Hispanic students. The remaining 3,536 institutions are $72 \%$ white and enroll the rest of the minority students. Within these institutions there is considerable variation in the institutional characteristics of those serving primarily either white or minority students.

Of the 30 institutions that serve numerically the most black students, 23 (77\%) are two-year colleges that award an associate degree in contrast to the 30 institutions that serve numerically the most white students, where only one (3\%) is a two-year college. For Hispanic students, 21 (70\%) of the top 30 are two-year colleges that give an associate degree. Twenty-nine of the top 30 white institutions are PhDgranting research universities. In contrast, only $5(17 \%)$ of black and $3(10 \%)$ of the Hispanic institutions grant a $\mathrm{PhD}$. In terms of geographic location, 28 (93\%) of the 30 institutions serving black students, and 21 (70\%) of the 30 institutions serving Hispanic students, are located in urban areas over 500,000; of those 30 institutions that serve white students, only 7 (23\%) are located in urban areas (see Figure 4).

In the 30 institutions with the largest white enrollments, Hispanics account for 5\% and blacks $6 \%$ of the students, despite the fact that all but one (Brigham Young) are public universities in states with a proportionally much larger minority population. In contrast, whites are a minority at the 30 institutions that enroll the largest numbers of Hispanic and black students, even though they are largely located in urban areas with a numerically large white population (see Figure 4).

A similar picture of racial selectivity results when the total enrollment of all 3,536 non-Puerto Rico, non-historic black colleges and universities are considered. The $252 \mathrm{PhD}$-granting institutions with a total of 3.7 million students, enroll $21 \%$ of all blacks, $18 \%$ of all Hispanics, but $29 \%$ of all whites. In contrast, the 1,571 two-year colleges, with a total enrollment of 3.9 million students, enroll $53 \%$ of all blacks, $60 \%$ of all Hispanics but only $40 \%$ of all whites.

These are not new findings. They are similar to previous analyses of enrollments in higher education for 1990-91 (Renner, 1993), 1993-94 (Renner, 1998), and 1998-99 (Renner, 2003). However, the implications of these statistics-that there are systemic reasons for them-have largely been ignored. 


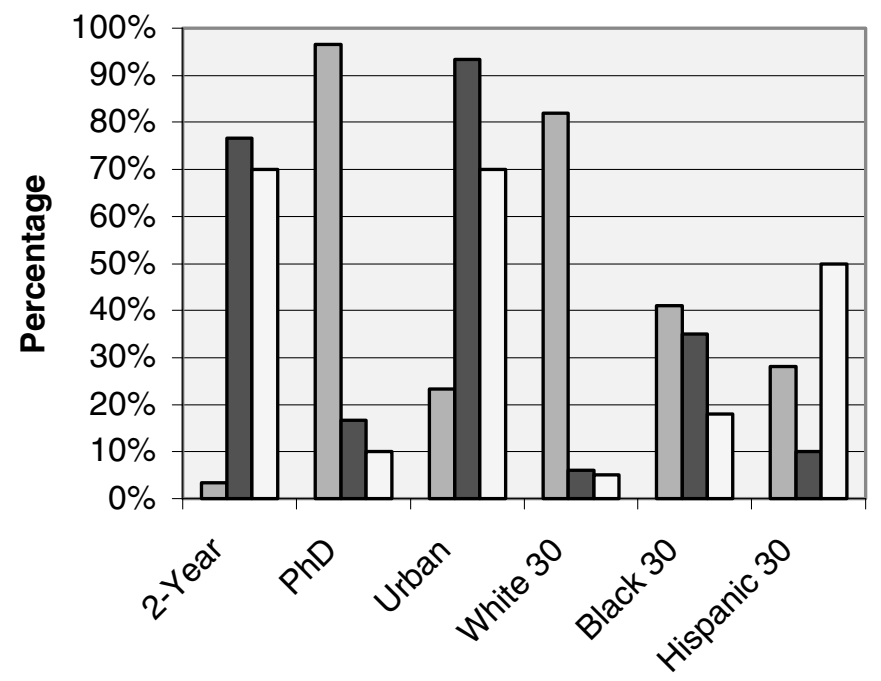

Institutional Description

\section{$\square$ White $\square$ Black $\square$ Hispanic}

Fig. 4. Institutional characteristics of 30 colleges with the largest white, black, and Hispanic enrollments. Data from the NCES 2003 Integrated Postsecondary Education Data System.

\section{The Mechanisms of Relative White Advantage}

There are a variety of admission policies and social circumstances operating parallel to affirmative action, but in the opposite direction. In overall effect, they have conferred a relative advantage to white students and contribute to the segregation of higher education. These have been elaborated on in detail elsewhere (Renner, 2003), but include:

- Pre-paid tax-exempt 529 tuition plans and tax-exempt tuition trusts that have served upper-income families while minorities have fallen further behind in their capacity to afford college as a percentage of total family income (Advisory Committee on Student Financial Assistance, 2001, 2002; General Accounting Office, 2002).

- Special admission consideration for children of alumni.

- Special admission consideration for children of university benefactors.

- Grade inflation throughout the 1990s and the period of the demographic depression.

- Lack of advanced courses in minority high schools. 
- High concentration of untrained teachers in minority schools (Jerald, 2002; NCES, 2003b)

- Lack of a computers and Internet access in minority schools (NCES, 2001).

- Lack of suitable on-campus minority supports including minority housing (Renner, 2003).

- Inadequate financial assistance for minority students that is compounded by the shift from need-based to merit-based financial aid (National Center for Public Policy in Higher Education, 2002, 2003).

For all of these policies there are "race neutral" explanations as to why they reflect sound educational policy dictated by external circumstances, often economics and population demographics. For example, in the 1960s higher education went through its expansion period to accommodate the baby boomers. Figure 5 provides a graphic picture of the "baby boomers," the peak of whom are now $45-50$ years of age. The figure also shows the "boomlet," the babies of the baby boomers who are now coming of college age. These two peaks on the population distribution of the United States are largely a white phenomenon. They can serve as a further example of how the mechanisms of relative white advantage work.
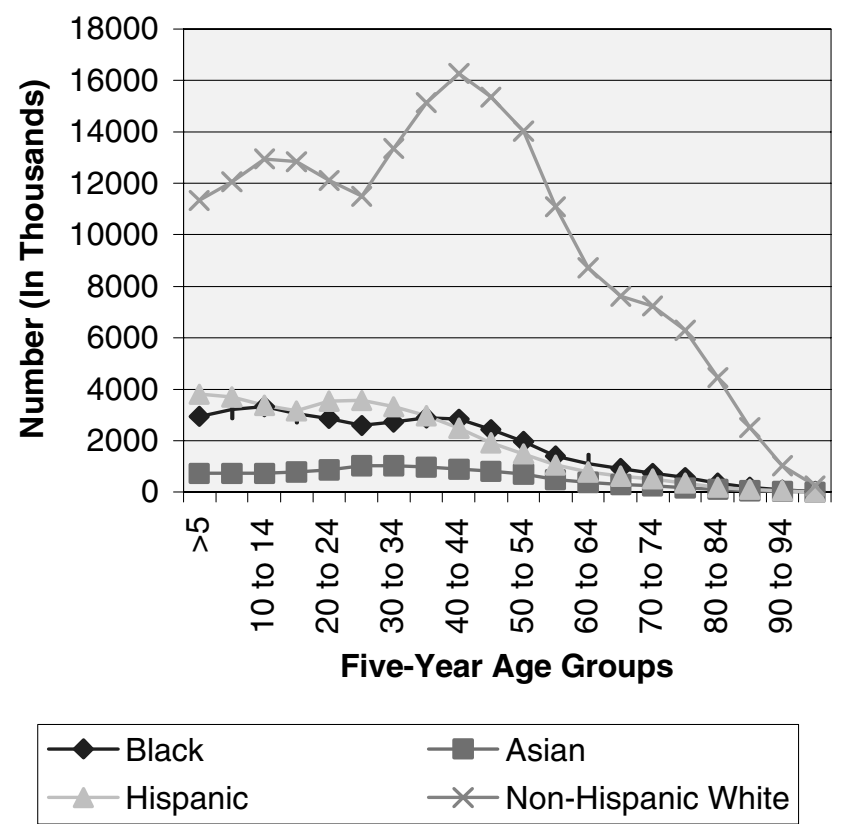

Fig. 5. Population distribution by age and race. U.S. Bureau of Census (2001b). 
Once the baby boomers graduated, higher education confronted the "demographic depression" by accommodating life-long learning, mature students, the emergence of grade inflation, and by providing increased remedial supports - all of which sustained existing enrollment and differentially benefited mostly white students by maintaining the status quo (Renner, 1993). However, once the boomlet arrived, there have been renewed efforts to bring grade inflation under control, raise admission standards, end remedial classes, raise tuition, and shift from need-based to merit-based financial aid. All of these policies have a differentially negative impact on minority students. For example, in 2003 the tuition at two-year colleges has gone up $15 \%$, yet these are the institutions that serve the majority of minority students (American Association of Community Colleges, 2003). The similar 14\% increase in tuition reported by the College Board (Farrell, 2003) at four-year public colleges is a lower percentage of family income for the baby boomers than for the majority of minority students who are being left behind financially in growing numbers (Advisory Committee on Student Financial Assistance, 2001, 2002).

Population demographics clearly have had an impact on higher educational policy, but in the opposite direction from what is dictated by the compelling demographic need to actually become a more equitable and diverse society. Such are the effects of subtle forms of supposedly "race neutral" polices and practices within higher education that maintain the status quo and help to account for the long list of mechanisms maintaining the relative white advantage for the past 60 years.

Typically, these mechanisms are not uniquely identified with an individual who can be held accountable for personally motivated discrimination. For this reason, outcomes must be used as the criteria for systemic discrimination. It is also the reason that broad non-personal corrective measures, such as busing or special admission procedures, are necessary to address the effects of systemic discrimination, and why outcome measures are required to monitor progress. When the numerical effects outlined at the start of this article no longer exist, affirmative action will no longer be needed. That time has not yet started.

\section{The Central Role of Equity}

Supporters of affirmative action need to use the extensive data showing there is currently racial inequality in higher education, and that it is the result of specific educational polices and practices that benefit primarily white students. Since every single educational policy and practice cannot be truly race neutral in terms of its outcome, such as legacy admissions, it is the balance that is the key to equity.

This essential legal issue was established in Brown v. The Board of Education (1954). It was that systemic discrimination is indexed by its outcomes, i.e., separate can never be equal. The negative consequences of inequality had to be eliminated in all the places in which they were manifested, from water fountains to public schools. The implication for higher education is that affirmative action should be required by the courts, just as desegregation was for public schools. 
In the case of higher education, the Supreme Court has established under Title VI of the Civil Rights Act of 1964 that race-based policies and practices will be upheld when they pass "strict scrutiny," which requires them to serve a compelling interest and be narrowly tailored (Palmer, 2001). In such instances, the courts require a basis in evidence that a voluntary race-based affirmative action policy is warranted to achieve equity. In the context of higher education the compelling justification is for remedying the effects of past discrimination. The legal foundation is Brown v. the Board of Education (1954), which rests firmly on considerations of equality. For public education, the result has been the legally enforced requirement by the courts to address the historical effects of discrimination and segregation in public education, frequently through busing.

Currently, the critics of affirmative action have been using the language of the civil rights movement to ague that affirmative action has favored minorities and is a form of discrimination against whites. However, the total set of admission standards, procedures, and policies that govern overall access to higher education, still favor whites. Their effect more than offsets the limited impact of admission procedures that supports minorities. Therefore, affirmative action must become a nationally mandated policy for numerical racial equality to be achieved, similar to what has taken place for gender equity in sports under Title IX of the Education Act of 1972 (Suggs, 2003). Indeed, similar to sports, any institution that argues that it need not have a program of affirmative action to address the lack of numerical racial equality should be subjected to strict scrutiny by the courts.

\section{The More Things Change the More They Stay the Same}

The idea that higher education has deceived itself, by seeming to change through touting the value of racial diversity, while actually staying the same by supporting an underlying pattern of discrimination, is not an easy conclusion to accept. If the goal of racial diversity had actually been achieved with Johnson's challenges in 1965, there would be numerical equity on our campuses and we would now be making real progress toward an educationally diverse culture, rather than struggling with the racial isolation that exists on most campuses.

Analogies are sometimes a useful way to gain added perspective on a point of view that is otherwise difficult to accept. With passage of the Fair Employment Act of 1938 we gave legislative standing to the concept of the right of workers to a fair wage, which at that time was 25 cents an hour for a workweek standardized at 40 hours. This standard took on new meaning when the Bureau of Census established the poverty line as a reported statistic. In 1959, 40 hours of work at the minimum wage supported a family of four at only $70 \%$ of the poverty line. This was a clear contradiction to the social justice politics of the 1960s and to the concept of a living wage. By the end of the "War on Poverty" in 1968, the minimum wage had increased to $\$ 1.60 /$ hour, which was at $94 \%$ of the poverty line for a family of four. However, once this period of social consciousness was over, 
a standard workweek at minimum wage declined to below $70 \%$ of the poverty line and has remained there for the past 20 years, even though the minimum wage increased to $\$ 5.15 /$ hour (Statistical Abstracts of the US, 2002b, 2002c).

Similarly, with respect to access to higher education, there was a temporary adjustment in the late 1960s to admit more minority students as we moved from the ideal of equal opportunity to the mechanism of affirmative action. In fact, the effect was small and short-lived (Renner, 1993). In the end, as with a living wage, the net gain is zero (see Figure 2). We have deceived ourselves by false statistics as having changed our fundamental values, and remain unable to confront the real issue by making the absolute compensations required to achieve racial equity as an outcome.

For institutions of higher education to primarily defend affirmative action in terms of the social value of diversity has been a strategic disaster. The recent ruling by the Supreme Court in the Michigan cases (Gratz v. Bollinger, 2003; Grutter v. Bollinger, 2003) has left affirmative action hanging by a thread that will soon be cut. The court's ruling only allowed that race may be used to achieve diversity under limited circumstances, not that race must be used whenever there are persistent effects of past and present discrimination (Palmer, 2001; Rosenfield, 1991). The opponents are now organizing to get other states, similar to California, Florida, and Washington, to ban the optional use of race in any form, even for statistical records. This will be the end of affirmative action, and the sad end to a chapter in the search for greater social justice through the institution of education. We are losing the fight to protect affirmative action, and to actually achieve racial equity, by a misplaced emphasis on "diversity," rather than on the central role of equity. The positive social goal of diversity can be reached only through equity, not the reverse.

\section{The Institutional Audit as a Prescription for Progress}

"Higher Education" has no central office, no budget, and no administrative authorities. Corrective measures, therefore, are a matter for individual institutional actions. These must begin with an internal audit to determine which mechanisms of relative white advantage contributed in what degree to racial inequality at that institution. The result is a prescriptive ledger for direct compensatory actions to be taken through each institution's admission policies and practices. The political problem with this recommendation is that officials of colleges and universities do not want to admit that their admission policies and practices have, and still do, discriminate against minorities.

However, the advantage of doing so is to deliberately expose individual institutions of higher education to effective litigation by minorities based on constitutional arguments of equality. This is the opposite of the current situation where institutions instead have chosen to expose themselves to legal actions by white 
students as a result of justifying affirmative action on diversity grounds. After all, it is the minorities, and not the whites, who should be making equity challenges and arguments in the courts, as did the minority students who gained intervener status in the Michigan cases (Shaw, 2003; Massie, 2003). Similar to the legal requirements stemming from Brown v. The Board of Education (1954), compensatory admission polices for minority students should be required by the courts, no less than busing followed the legal requirement for desegregation of the public schools.

Ideally, the administrative officers at each institution would take the lead in conducting an internal audit to identify the mechanisms of their own institution's contribution to the cumulative relative white advantage. However, leadership from the President's Office, although desirable, is not essential. Smaller-scale local audits can be undertaken at the departmental or faculty levels where many relevant decisions are made and implemented. In the historical tradition of SPSSI for critical empirical analysis of social policy, individual faculty members can conduct and publish independent evaluation research based on publicly available university records. This is appropriate public interest scholarship "to be of use" (Fine \& Barreras, 2001), and to energize an open and informed institutional discussion.

Further, the scope of institutional audits should also include the quality of campus life. Many institutions need to acknowledge that although diversity has been used as a rationale for admission policy it has not been an effective element of campus life. Clearly, racial diversity is an important social and cultural value (Bowen \& Bok, 1998). But it is not an effective instrumental mechanism for social change. Rather, equity is the foundation for social justice, and it is the tool for actual change. The simple concept of equity established in Brown v. The Board of Education, that separate can never be equal, was, and still is, the engine for social change. We cannot go from desegregation to equity through diversity. We can get from desegregation to diversity through equity.

It is time for higher education to examine its policies and practices, and to return to the challenges set by Johnson in 1965 with Executive Order 11246, and to the legal standard set by the Supreme Court in Brown v. The Board of Education (1954). It is time to recognize the conceptual and strategic disaster that will now flow from the Gratz v. Bollinger (2003) and the Grutter v. Bollinger (2003) decisions, and to get on with the task of desegregating higher education through numerical equity as the constitutional instrument of change to achieve social justice, and with it, true racial diversity.

\section{The Elusive Goal of Social Justice}

The Advisory Committee on Student Financial Aid (2001) in its annual report to Congress documents that "... the cost of higher education has risen steadily as a percentage of family income only for low income families." The report also states: "Three decades ago, there was unanimous agreement to the nation's 
access goal: low-income students who are academically prepared must have the same educational opportunity as their middle- and upper-income peers. Today that opportunity... is all but ruled out for increasing number of low-income students by records levels of unmet needs."

In meeting the challenge of access to higher education, both poverty and race are relevant; neither should be used as a proxy for the other. Both need to be confronted on their own terms. However, race and poverty are linked, and the dual disadvantage cannot be resolved simply by responding to poverty alone as a sufficient response to racial inequality. Poverty is not race neutral. It falls disproportionately on minority students, and it is a deception to treat responses to poverty as an adequate solution to racial inequality in access to higher education.

Black and Hispanic families are three times more likely than white families to be below the poverty line (U.S. Bureau of Census, 2000a). A black child is over three times ( $28 \%$ versus $8 \%$ ) more likely to live in a single-parent female household (U.S. Bureau of Census, 2000b); further, 30\% of all black and Hispanic children live below the poverty line, which is 2.5 times higher than the rate for white children (U.S. Bureau of Census, 2001a).

Census 2000 also documents the many ways that blacks and Hispanics are in an unequal position in the competition for access to higher education. As recently as 1995 schools where less than $35 \%$ of the students were eligible for a free or reduced price lunch were twice as likely to have Internet access as schools where $75 \%$ or more were eligible. A $21 \%$ gap still exists in the number of classrooms with Internet access between schools with less than $6 \%$ minority enrolment and those with $50 \%$ or more (NCES, 2001). The effect of these kinds of background preparations will continue to ripple through the educational system for many years to come, particularly when reinforced by the many other mechanisms that disadvantage the minorities, such as lack of advanced classes and large numbers of out-of-field teachers in schools were minority children are concentrated (Jerald, 2002).

Of course, colleges and universities are correct that they would be better able to grant access if more minority students were better qualified at the time of high school graduation. In turn, the high schools could do a better job if minority students were better qualified at the elementary and middle school level. And, the elementary and middle schools could do a better job if their students received proper nutrition as infants, came from fewer single-parent families, and lived in less poverty.

While it is true that no institution alone can end the impact of inequality and discrimination, neither can any wait until all the others first do a better job so that they in turn can finally do their job. The negative effects of inequality are cumulative and interactive. Change at any level creates change at every other level. More minority college graduates reduce poverty, provide role models, promote integration, and ultimately enable the positive social goal of diversity. 
When institutions of higher education take remedial steps to correct their own institutional role in the vicious circle of maintaining the mechanisms of relative white advantage at their institution, a solid majority of the Supreme Court agrees that this interest remains sufficiently compelling to support race-based affirmative action (Palmer, 2001).

There are compelling demographic, social, political, economic, and educational reasons for returning to an equity foundation for affirmative action. The racial inequalities in this country already stand in stark contradiction to our worldwide stand against human rights violations in other countries. In terms of the new demographics of America there is a compelling national urgency that goes to the core of our democratic foundation to address the contradiction between what we say and what we do about racial inequities.

In 2001 (U.S. Bureau of Census, 2001b), non-Hispanic whites accounted for $69 \%$ of the total population. By the year 2050 that percentage is projected to decline to 53\% (U.S. Bureau of Census, 2000c). The mechanism for this demographic transformation can be seen in the racial composition of the age distribution of the population. The majority of the non-Hispanic white population is now older than the typically child-bearing age, whereas the majority of the non-white population are either children or young adults (see Figure 5).

Minorities now comprise $40 \%$ of the people who are under 25 years of age. Where are the teachers and leaders to come from when a high percentage of this group is confined to poverty? How much political power and wealth can an aging white population control without fracturing the democratic ideal of the nation along a racial divide? The greater the economic gap, the more self-fulfilling the consequences of racial inequality will become. The time is long past for breaking this cycle for which fair and equal access to the benefits of education, at all levels, is essential.

\section{References}

Advisory Committee on Student Financial Assistance. (2001). Access denied: Restoring the nation's commitment to equal educational opportunity. Washington, DC: U.S. Department of Education.

Advisory Committee on Student Financial Assistance. (2002). Empty promises: The myth of college access in America. Washington, DC: U.S. Department of Education.

Allen, W. R. (2000). The struggle continues: Race, equity and affirmative action in U.S. higher education. In Lee Daniels (Ed.), The state of black America 2001. Washington, DC: National Urban League.

Allen, W. R., Teranishi, R., Dinwiddie, G., \& Gonzalez, G. (2000). Knocking at freedom's door: Race, equity and affirmative action in U.S. higher education, Journal of Negro Education, 69, 3-11.

American Association of Community Colleges. (2003). Community college tuition survey, www.aacc. nche.edu.

American Council on Education. (2003). Minorities in higher education 2002-2003: Twentieth annual status report. Washington, DC.

Bowen, W. E., \& Bok, D. (1998). The shape of the river: Long-term consequences of considering race in college and university admissions. Princeton, NJ: Princeton University Press. 
Brown v. The Board of Education of Topeka. (1954). 347 U.S. 237.

Farrell, E. F. (2003). Public-college tuition rise is largest in 3 decades. The Chronicle of Higher Education, Oct. 31, 10a.

Fine, M., \& Barreras, R. (2001). To be of use, Analysis of Social Issues and Public Policy, 1, 175-182.

General Accounting Office, U.S. Government. (2002). Student aid and tax benefits, Washington, D.C., GAO-02-751.

Gratz v. Bollinger. (2003). Docket Number 02-516.

Grutter v. Bollinger (2003). Docket Number 02-241.

Jerald, C. D. (2002). All talk, no action: Putting an end to out-of-field teaching. Washington, DC: Education Trust.

Johnson, L. B. (1965a). Executive Order 11246: Equal employment opportunity, Sept. 24, 1965, Code of Federal Regulations. Federal Register: Washington, D.C.: U.S. Government Printing Office, 1967.

Johnson, L.B. (1965b). To fulfil these rights. Commencement Address, Howard University, Washington, D.C., June 4.

Massie, M.K.S. (2003). Brief for the Intervenors in Grutter v. Bollinger. Supreme Court of the United States, No. 02-241.

National Center for Public Policy and Higher Education. (2002). Losing ground: A national status report on the affordability of American higher education. San Jose, CA.

National Center for Public Policy and Higher Education. (2003). College affordability in jeopardy. San Jose, CA.

NCES (2001). Internet access in U.S. public schools and classrooms: 1994-2000. In Statistical Abstracts of the US. (2002). U. S. Bureau of Census, Table 236.

NCES (2003a). Integrated postsecondary education data system. U.S. Department of Education, http://nces.ed.gov/ipeds.

NCES (2003b). Qualifications of the public school workforce: Prevalence of out-of-field teaching 1987-88 to 1999-2000. Washington, DC: U.S. Department of Education.

Palmer, S. (2001). Diversity and affirmative action: Evolving principles and continuing legal battles. In G. Orfield (Ed.), Diversity challenged: Evidence on the impact of affirmative action. Cambridge, MA: Harvard Educational Publishing Group.

Regents of the University of California v. Bakke. (1978). 438 U.S. 265, 278.

Renner, K. E. (1993). On race and gender in higher education: Illusions of change. Educational Record, 74(4), 44-48.

Renner, K. E. (1998). Redefining the issue of racial preference: Minority access to higher education. Change, 30(2), 26-33.

Renner, K. E. (2003). Racial equity and higher education. Academe, 89(1), 38-43.

Rosenfield, M. (1991). Affirmative action and justice: A philosophical and constitutional inquiry. New Haven, CT: Yale University Press.

Shaw, T.M. (2003). Brief for the Intervenors in Gratz \& Hamacher v. Bollinger. Supreme Court of the United States, No. 02-516.

Statistical Abstracts of the US. (2002a). U.S. Bureau of Census, Table 208 for recent data.

Statistical Abstracts of the US. (2002b). U.S. Bureau of Census, Table 616.

Statistical Abstracts of the US. (2002c). U.S. Bureau of Census, Table 670.

Suggs, W. (2003). Education department stands pat on Title IX. Chronicle of Higher Education, Vol 49, $46 \mathrm{a}$.

U.S. Bureau of Census. (2000a). Census 2000. In Statistical Abstracts of the US. (2002). U.S. Bureau of Census, Table 36.

U.S. Bureau of Census. (2000b). Census 2000. In Statistical Abstracts of the US. (2002). U.S. Bureau of Census, Table 37.

U.S. Bureau of Census. (2000c). Census 2000. In Statistical Abstracts of the US. (2002). U. S. Bureau of Census, Table 16.

U.S. Bureau of Census. (2001a). Current population reports, P60-214. In Statistical Abstracts of the US. (2002). U.S. Bureau of Census, Table 669.

U.S. Bureau of Census. (2000b). Unpublished data. In Statistical Abstracts of the US. (2002). U.S. Bureau of Census, Table 15. 
EDWARD RENNER is an Adjunct Professor of Psychology at the University of South Florida. He is also an independent consultant on evaluation research (www.kerenner.com). In addition to his research on higher education, he is the co-principle investigator for an international project on the legal aspect of sexual assault (www.napasa.org).

THOM MOORE is an Adjunct Professor of Psychology, and Director of the Psychological Services Center at the University of Illinois at Urbana-Champaign. He has been involved in education for most of his career. More recently he has been involved with training students and working with grassroots community development. 